\title{
Varietal Differences in Rooting Ability of In Vitro Subcultured Japanese Persimmon Shoots
}

\author{
Hirokazu Fukui, Kazuo Nishimoto and Mitsuo Nakamura \\ Faculty of Agriculture, Gifu University, Gifu 501-11
}

\begin{abstract}
Summary
In vitro rooting ability was investigated in 95 Japanese persimmon (Diospyros kaki Thunb.) cultivars and three other species by repeatedly subculturing shoots which were treated with a synthetic rooting hormone. Of the $D$. kaki cultivars, the 25 which failed to root were categorized as not having any potential to root. The remaining 70 which rooted to varying degree were classified into three groups, namely, low-rooting ability ( $31 \mathrm{cvs}$.), medium-rooting ability ( 23 cvs.), and high-rooting ability (16 cvs.). A relationship between rooting ability and tree vigor was noted, that is, the vigorous cultivars had better rooting percentages than had those which were less vigorous. The pollination constant and astringent (PCA) type cultivars were difficult to root. Japanese persimmons were classified into three types based on the relation between number of roots and the longest root.
\end{abstract}

\section{Introduction}

There are more than 1,000 Japanese persimmon cultivars; their fruit, shoot, and flowering characteristics have been described in a report by the Hiroshima Experimental Research Station (7). Recently, they were classified by isozymes $(12,13)$ and by their ethanol productivity and tannin content (10).

Propagation of Japanese persimmon by soft- and hard-wood cuttings has not been too successful. However, clonal propagation by shoot tip culture $(1,4,11)$ has been successfully accomplished in recent years, provided shoot tips are subcultured repeatedly $(3,6,11)$. Nevertheless, varietal differences in rooting ability have appeared $(3,6)$. The rooting ability in a species or variety is promoted by auxin and/or rooting cofactors in the shoots which are controlled genetically. These inherent characteristics are supposed to be stable in vitro; they function physiologically, so that they are used to classify organogenetic potential in rice (14), Chinese cabbage (8), wheat (9), and Japanese persimmon (5).

In this study, shoot apices from a large population of $D . k a k i$ and three other species were as-

Received for publication 22 April 1991. sayed in vitro for their rooting ability and classified accordingly.

\section{Materials and Methods}

Shoot tips excised from current growth of 95 Japanese persimmon (Diospyros kaki Thunb.) cultivars and three other species, D. japonica, D. lotus (male plant), and D. virginiana (male and female plant) were cultured in Murashige and Skoog's medium containing half-strength nitrogen $(1 / 2 \mathrm{~N}$ MS) plus $10^{-5} \mathrm{M}$ zeatin, 3\% sucrose and $0.7 \%$ agar $(4,5)$. Subsequently the shoots were repetitively subcultured every six weeks in a fresh medium for 27 months. Shoots were treated with $\alpha$-naphthyl acetamide powder (containing $0.40 \% \alpha$ naphthyl acetamide) to induce rooting (3), and then cultured on the $1 / 2 \mathrm{~N}-\mathrm{MS}$ medium containing $3 \%$ sucrose and $0.7 \%$ agar (zeatin free). Data were obtained from 10 shoots per cultivar and the different Diospyros species 6 weeks after culturing.

\section{Results and Discussion}

No roots were obtained in $25 \%$ of the kaki cultivars (Table 1); they were classified as "difficultto-root". The percentage of shoots of the remaining cultivars which formed roots ranged from 10 to $100 \%$. Of these cultivars, 31 had rooting percentage of less than $30 \%$, and these were classified as 
Table 1. Variations in rooting observed in 95 Japanese persimmon cultivars and three Diospyros species.

\begin{tabular}{|c|c|c|c|c|c|}
\hline Cultivars and species & $\begin{array}{l}\text { No. of rooted } \\
\text { shoots }\end{array}$ & $\begin{array}{l}\text { No. of roots per } \\
\text { rooted shoots }\end{array}$ & $\begin{array}{l}\text { The longest root } \\
\text { length }(\mathrm{mm})\end{array}$ & Fruit type ${ }^{z}$ & Tree vigor ${ }^{y}$ \\
\hline Aburatsubo & $3 / 10$ & $1.3 \pm 0.6^{\mathrm{x}}$ & $10.0 \pm 4.4^{x}$ & PVNA & 4 \\
\hline Akagaki & $6 / 10$ & $2.2 \pm 1.5$ & $11.3 \pm 9.6$ & PVNA & 5 \\
\hline Ama Hyakume & $4 / 10$ & $2.3 \pm 1.3$ & $8.0 \pm 2.4$ & PVNA & 7 \\
\hline Ama Yotsumizo & $1 / 10$ & 2.0 & 15.0 & PVNA & 6 \\
\hline Aosa & $3 / 10$ & $1.7 \pm 0.6$ & $13.3 \pm 5.5$ & $\mathrm{PCA}$ & 6 \\
\hline Aoso & $1 / 10$ & 2.0 & 12.0 & PCA & 7 \\
\hline Atago & $0 / 10$ & - & - & PCA & 7 \\
\hline Beni Emon & $7 / 10$ & $1.3 \pm 0.5$ & $13.6 \pm 9.6$ & PVA & 5 \\
\hline Benigaki & $7 / 10$ & $3.4 \pm 1.1$ & $42.9 \pm 13.2$ & $\mathrm{PCA}$ & 6 \\
\hline Beni Hagakushi & $5 / 10$ & $1.8 \pm 0.8$ & $9.8 \pm 7.2$ & PCA & 7 \\
\hline Da Mo Pan & $0 / 10$ & - & - & PCA & 7 \\
\hline Dojo Hachiya & $4 / 10$ & $3.0 \pm 0.8$ & $28.8 \pm 17.7$ & PCA & 5 \\
\hline Ebo & $3 / 10$ & $1.7 \pm 0.6$ & $9.5 \pm 10.0$ & PVA & 5 \\
\hline Eboshi & $8 / 10$ & $2.9 \pm 1.2$ & $29.1 \pm 13.6$ & PVA & 6 \\
\hline E Gosho & $10 / 10$ & $1.8 \pm 0.8$ & $8.8 \pm 5.9$ & PVNA & 3 \\
\hline Emon & $0 / 9$ & - & - & PVA & 5 \\
\hline Fujiwara Gosho & 217 & 2.0 & $13.0 \pm 1.4$ & PCNA & 4 \\
\hline Fuyu & $9 / 10$ & $2.1 \pm 0.8$ & $28.9 \pm 11.3$ & PCNA & 6 \\
\hline Hagakushi & $2 / 10$ & $2.0 \pm 0.1$ & $19.1 \pm 15.6$ & $\mathrm{PCA}$ & 7 \\
\hline Hegurogaki & $6 / 10$ & $4.8 \pm 2.8$ & $41.2 \pm 13.8$ & PVNA & 5 \\
\hline Hiratanenashi & $9 / 10$ & $2.0 \pm 0.9$ & $36.4 \pm 30.2$ & PVA & 7 \\
\hline Houtoku & $0 / 10$ & - & - & PVA & 4 \\
\hline Ibogaki & $1 / 10$ & 1.0 & 6.5 & PCA & 4 \\
\hline Ichidagaki & $2 / 10$ & $1.0 \pm 0.1$ & $15.5 \pm 3.5$ & PCA & 5 \\
\hline Ichiryo & $6 / 10$ & $1.5 \pm 0.8$ & $23.8 \pm 6.4$ & $\mathrm{PCA}$ & 6 \\
\hline Ikutomi & $4 / 10$ & $2.0 \pm 1.4$ & $28.6 \pm 18.3$ & PCNA & 7 \\
\hline Inasa & $4 / 10$ & $3.0 \pm 1.4$ & $45.0 \pm 31.1$ & PCA & 7 \\
\hline Inayama & $0 / 10$ & - & - & PCA & 6 \\
\hline Iwasedo & $0 / 8$ & - & - & PCA & 7 \\
\hline Izaemon & $0 / 10$ & - & - & PVA & 5 \\
\hline Jisha & $0 / 10$ & - & - & PCA & 5 \\
\hline Kawabata & $0 / 7$ & - & - & PCA & 5 \\
\hline Konashiba & $4 / 10$ & $1.5 \pm 0.6$ & $17.3 \pm 11.6$ & PVNA & 4 \\
\hline Koshu Hachiya & $4 / 10$ & $3.0 \pm 2.8$ & $11.5 \pm 9.5$ & PCA & 5 \\
\hline Koshumaru & $1 / 10$ & 2.0 & 13.0 & PVA & 5 \\
\hline Koshushi & $1 / 10$ & 4.0 & 40.0 & PCA & 7 \\
\hline Kubo & $8 / 10$ & $2.4 \pm 1.4$ & $12.5 \pm 7.1$ & PVNA & 7 \\
\hline Kubogata Obishi & $3 / 10$ & $1.7 \pm 0.6$ & $19.0 \pm 1.0$ & PVNA & 4 \\
\hline Kurogaki & $5 / 9$ & $1.6 \pm 0.5$ & $15.2 \pm 3.7$ & PVNA & 3 \\
\hline Kyara & $0 / 10$ & - & - & PVNA & 7 \\
\hline Mammoth & $3 / 10$ & $4.3 \pm 3.2$ & $45.0 \pm 22.1$ & PCNA & - \\
\hline Mikagemaru & $7 / 10$ & $1.7 \pm 0.8$ & $24.0 \pm 16.6$ & $\mathrm{PCA}$ & 6 \\
\hline Mikatani Gosho & $2 / 10$ & $2.5 \pm 2.1$ & $30.0 \pm 12.7$ & PVNA & 7 \\
\hline Mizuta Fuyu & $2 / 8$ & $1.5 \pm 0.7$ & $21.0 \pm 1.4$ & PVNA & 5 \\
\hline Monpei & $7 / 10$ & $2.1 \pm 0.9$ & $23.3 \pm 15.1$ & PVA & 6 \\
\hline Mushiroda Gosho & $0 / 10$ & - & - & PCNA & 2 \\
\hline Nagano Gosho & $0 / 10$ & - & - & PVNA & 5 \\
\hline Nagatorogaki & $0 / 10$ & - & - & $\mathrm{PCA}$ & 5 \\
\hline Nage Eboshi & $0 / 10$ & - & - & PCA & 5 \\
\hline Nishimurawase & $9 / 10$ & $2.3 \pm 1.3$ & $26.0 \pm 13.4$ & PVNA & 4 \\
\hline Oshoro & $6 / 10$ & $3.3 \pm 3.3$ & $9.7 \pm 6.4$ & PVNA & 6 \\
\hline O Yotsumizo & $0 / 10$ & - & - & PCA & 5 \\
\hline Rendaiji & $0 / 10$ & - & - & PVNA & 4 \\
\hline Saijo & $1 / 10$ & 1.0 & 5.5 & PCA & 7 \\
\hline
\end{tabular}


(continued)

\begin{tabular}{|c|c|c|c|c|c|}
\hline Sakushu Mishirazu & $5 / 10$ & $2.0 \pm 1.2$ & $21.8 \pm 14.5$ & PVA & 4 \\
\hline Sanja & $3 / 10$ & $2.0 \pm 1.7$ & $14.7 \pm 6.1$ & $\mathrm{PCA}$ & 3 \\
\hline She Gu Shi & $7 / 11$ & $3.0 \pm 2.0$ & $82.4 \pm 25.9$ & $\mathrm{PCA}$ & 4 \\
\hline Shidaregaki & $1 / 10$ & 1.0 & 5.0 & PCA & - \\
\hline Shiga tanenashi & $1 / 10$ & 2.0 & 22.0 & $\mathrm{PCA}$ & 6 \\
\hline Shin Hachiya & $2 / 10$ & $3.5 \pm 3.5$ & $17.5 \pm 13.4$ & PVA & 4 \\
\hline Shinpei & $0 / 10$ & - & - & $\mathrm{PCA}$ & 7 \\
\hline Shiro Nippon & $6 / 10$ & $2.5 \pm 1.0$ & $11.0 \pm 5.1$ & PCA & 6 \\
\hline Shirotodamashi & $4 / 10$ & $1.5 \pm 1.0$ & $11.0 \pm 6.5$ & PCA & 5 \\
\hline Shogatsu & $6 / 10$ & $1.3 \pm 0.5$ & $18.1 \pm 13.2$ & PVNA & 5 \\
\hline Shoro & $8 / 10$ & $3.1 \pm 1.7$ & $22.1 \pm 5.5$ & PVNA & 6 \\
\hline Shuren & $3 / 10$ & $3.3 \pm 2.5$ & $55.0 \pm 11.0$ & PCA & 4 \\
\hline Suruga & $6 / 10$ & $1.3 \pm 0.5$ & $12.2 \pm 8.4$ & PCNA & 6 \\
\hline Takeda & $9 / 10$ & $2.8 \pm 1.1$ & $15.8 \pm 10.5$ & PCA & 6 \\
\hline Tateishi & $6 / 10$ & $1.3 \pm 0.5$ & $11.5 \pm 9.6$ & PCA & 5 \\
\hline Tenjin Gosho & $0 / 10$ & - & - & PCNA & 4 \\
\hline Tenryubo & $1 / 10$ & 3.0 & 11.0 & PVNA & 4 \\
\hline To Gosho & $3 / 10$ & $2.3 \pm 1.5$ & $29.7 \pm 12.9$ & PCNA & - \\
\hline Tohachi & $7 / 10$ & $3.4 \pm 1.3$ & $21.0 \pm 7.2$ & PVNA & 5 \\
\hline Toyoichi & $6 / 10$ & $2.2 \pm 1.0$ & $24.3 \pm 22.9$ & PVNA & 7 \\
\hline Toyooka & $10 / 11$ & $2.5 \pm 1.2$ & $8.6 \pm 5.2$ & PVNA & 7 \\
\hline Tsukiyo & $2 / 10$ & $1.5 \pm 0.7$ & $35.7 \pm 21.9$ & PVNA & 5 \\
\hline Tsunomagari & $0 / 10$ & - & - & PCA & 3 \\
\hline Tsurunohashi & $0 / 10$ & - & - & PCA & 5 \\
\hline Tsurunoko & $2 / 10$ & 1.0 & $15.0 \pm 12.7$ & PVA & 3 \\
\hline Wakamiya & $1 / 10$ & 8.0 & 27.0 & $\mathrm{PCA}$ & 4 \\
\hline Wasamatsuo & $0 / 10$ & - & - & PCA & 5 \\
\hline Wase Jisha & $0 / 10$ & - & - & PCA & 5 \\
\hline Watarizawa & $0 / 10$ & - & - & PCA & 5 \\
\hline Yamato & $0 / 10$ & - & - & $\mathrm{PCA}$ & 7 \\
\hline Yamatogaki & $8 / 10$ & $1.6 \pm 0.7$ & $14.6 \pm 8.2$ & PVNA & 5 \\
\hline Yamato Hyakume & $7 / 11$ & $2.1 \pm 1.2$ & $11.1 \pm 4.8$ & PVA & 6 \\
\hline Yamato Gosho & $8 / 10$ & $1.8 \pm 1.0$ & $21.6 \pm 12.6$ & PCNA & 7 \\
\hline Yashima & $3 / 10$ & $1.0 \pm 0.0$ & $7.7 \pm 3.2$ & PVNA & 5 \\
\hline Yokono & $4 / 10$ & $2.0 \pm 1.2$ & $13.0 \pm 11.9$ & PCA & 6 \\
\hline Yonsungaki & $1 / 10$ & 1.0 & 7.0 & $\mathrm{PCA}$ & 6 \\
\hline Yoshimoto Gosho & $0 / 10$ & - & - & PCNA & 5 \\
\hline Yoshino & $4 / 10$ & $1.3 \pm 0.5$ & $15.3 \pm 13.4$ & PVA & 4 \\
\hline Yotan & $2 / 10$ & $1.0 \pm 0.0$ & $30.5 \pm 2.1$ & PVNA & 4 \\
\hline Yotsumizo & $2 / 10$ & $2.0 \pm 1.4$ & $8.5 \pm 6.4$ & PCA & 6 \\
\hline Yukineri & $2 / 10$ & $1.0 \pm 0.0$ & $16.0 \pm 8.5$ & PVNA & 5 \\
\hline D. lotus $(\S)$ & $2 / 8$ & $11.5 \pm 9.2$ & $11.0 \pm 2.8$ & - & - \\
\hline D. japonica & $4 / 10$ & $2.5 \pm 1.0$ & $20.8 \pm 12.0$ & - & - \\
\hline D. virginiana (ङ) & $6 / 10$ & $8.8 \pm 5.6$ & $34.0 \pm 17.4$ & - & - \\
\hline D. virginiana $(\odot)$ & $10 / 10$ & $9.4 \pm 4.0$ & $19.5 \pm 11.5$ & - & - \\
\hline
\end{tabular}

" PCNA shows pollination constant and non-astringent type. PVNA shows pollination variant and non-astringent type. PVA shows pollination variant and astringent type. PCA shows pollination constant and astringent type.

$y$ The following value of tree vigor is based on the investigation at Hiroshima Prefecture (7), 2; very Peak, 3; weak, 4; slightly weak, 5 ; medium, 6 ; slightly vigorous, and 7; vigorous.

$\times$ The mean \pm standard deviation.

"cultivars of low rooting ability". D. lotus (male plant) was included in these group. Twenty-three cultivars had rooting percentages ranging from 40 to 60; they are considered "cultivars of medium rooting ability". This group includes $D$. japonica and male plants of $D$. virginiana. The 16 cultivars 
and the female plant of $D$. virginiana, in which more than $70 \%$ of the shoots rooted are classified as the high rooting ability group. Of all the cultivars and Diospyros species examined, $42.2 \%$ were in the medium and high rooting groups.

Soft- and hard-wood cuttings of Japanese persimmon taken from current or biennial shoots have been very difficult to root. However, in this experiment, shoots of many cultivars produced roots in vitro. In general, shoots in the juvenile phase, that is, shoots of young seedlings and water sprouts arising from the trunk near the soil surface are known to root readily. Franclet et al. (2) suggested that the degree of rejuvenation increased by repetitive subculturing. Therefore, the shoots propagated in vitro might revert the juvenile phase, because repetitive subculturing on the medium containing zeatin reverted shoots from the adult phase to the juvenile phase.

Successful in vitro rooting has been accomplished in 3 Japanese persimmons: 'Hiratanenashi' (11), 'Gailey' (1) and 'Nishimurawase' (6). In this experiment, a rooting percentage of $90 \%$ was attained with 'Nishimurawase' and 'Hiratanenashi' which agree with the findings of the previous reports.

We also found a relation between rooting ability and tree vigor in this trial. The classification of tree vigor was based on the investigations of growth of current shoots at the Hiroshima Experimental Research Station (7), where the cultivars were ranked in vigor from 1 to 7 . Twenty-three cultivars were ranked between 2 to 4 in vigor; their mean rooting percentage was 29.5. Thirty-nine vigorous cultivars which were ranked from 6 to 7 had a mean rooting percentage of 41.4. From these data, we concluded that the vigorous cultivars had a much better rooting ability than less vigorous ones.

Sixteen of the 25 cultivars which failed to root were the pollination constant and astringent (PCA) type (Table 1). Of the 43 PCA cultivars assayed, 30,10 , and 3 were classified as having; low $(<$ $30 \%$ ), medium ( 40 to $60 \%$ ), and high-rooting ability (more than $70 \%$ ), respectively. It was concluded that the PCA type cultivars were difficult to root. Of the pollination variant and astringent (PVA) type, 7, 3, and 4 cultivars were classified as being low-, medium-, and high- rooting ability, respectively, whereas of the 38 pollination variant

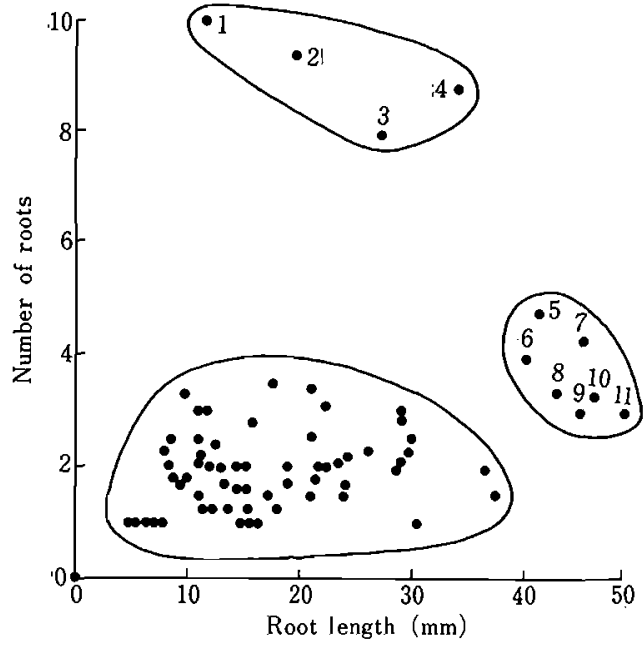

Fig. 1. Distribution of root length and number of roots. 1: Diospyros lotus (ब), 2: D. virginiana (Q), 3: Wakamiya, 4: D. virginiana (๑), 5: Hegurogaki, 6: Koshushi, 7: Mammoth, 8: Benigaki, 9: Inasa, 10: Shuren, 11: She Gu Shi.

and non-astringent (PVNA) type, 19, 10, and 9 were grouped as low-, medium-, and high-rooting ability, respectively.

Number of roots in Japanese persimmon was about two except for 'Wakamiya' (Table 1), and that of $D$. lotus and $D$. virginiana was about ten. It was observed that the roots of $D$. kaki seedlings (Japanese persimmon) are composed of a tap root and few lateral roots, whereas the roots of $D$. $l o$ tus seedlings are composed of many lateral roots and fine roots. Therefore, the root system in orchard may have relation to the number of roots developed in vitro.

Fig. 1 shows a relation between number of roots and length of the longest root. 'Wakamiya', D. lotus and $D$. virginiana produced many roots which were obviously different from other Japanese persimmons. 'Benigaki', 'Hegurogaki', 'Inasa', 'Koshushi', 'Mammoth', 'She Gu Shi' and 'Shuren' had long roots and comparatively large numbers of roots, therefore these cultivars were distinguishable from the other Japanese persimmons.

\section{Literature Cited}

1. Cooper, P.A. and D. Cohen. 1985. Micropropagation of Japanese persimmon (Diospyros kaki). Proc. Int. Plant Prop. Soc. $34: 118-124$. 
2. Franclet, A., M. Bouley, F. Bekkaoui, Y. Fouret, B. Verschoore-Martouzet, and N. Walker. 1987. Rejuvenation. p.232-248. In: J. M. Bonga and D. J. Durzan (eds.). Cell and tissue culture in forestry vol. 1. Martinus Nijhoff Publishers, Dordrecht.

3. Fukui, H., K. Nishimoto, I. Murase and M. Nakamura. 1988. Effect of rooting induction treatments and sucrose concentrations in medium on in vitro rooting of Japanese persimmon ( $D i$ ospyros kaki Thunb.). Res. Bul. Fac. Agr., Gifu Univ. (53) : 133-137. (In Japanese).

4. Fukui, H., M. Sugiyama and M. Nakamura. 1989. Shoot tip culture of Japanese persimmon (Diospyros kaki Thunb.). J. Japan. Soc. Hort. Sci. $58: 43-47$. (In Japanese).

5. Fukui, H., K. Nishimoto and M. Nakamura. 1990. Varietal differences in shoot tip culture of Japanese persimmon (Diospyros kaki Thunb.). J. Japan. Soc. Hort. Sci. $59: 51-57$.

6. Fumuro, M., H. Murayama, R. Tao, R. Murata and A. Sugiura. 1988. Studies on rearing of dwarfing rootstocks for Japanese persimmon. (1). In vitro propagation a dwarf strain of $\mathrm{cv}$. 'Nishimurawase'. Bul. Shiga Pref. Agric. Exp. Sta. $29: 20-32$. (In Japanese)

7. Hiroshima Prefecture. 1978. Shouwa 53 nendo shubyou tokusei bunrui chousa houkokusho (Kaki). p.1-426. Hiroshima Experimental Research Station, Hiroshima. (In Japanese).

8. Sato, T., T. Nishino and M. Hirai. 1989. Varietal differences in embryogenic ability in anther culture of Chinese cabbage (Brassica campestris ssp. pekinensis). Japan. J. Breed. 39 : 149-157.

9. Shimada, T. and M. Otani. 1989. Varietal differences in green plant regeneration ability of wheat pollen embryoids. Japan. J. Breed. 39 : 187-194.

10. Sugiura, A. and T. Tomana. 1983. Relationships of ethanol production by seeds of different types of Japanese persimmons and their tannin content. HortScience $18: 319-321$.

11. Sugiura, A., R. Tao, H. Murayama and T. Tomana. 1986. In vitro propagation of Japanese persimmon. HortScience $21: 1205-1207$.

12. Sugiura, A., R. Tao and T. Tomana. 1988. Distinguishing between Japanese persimmon cultivars (Diospyros kaki L.) by means of pollen isozymes. Scientia Hortic. 36:67-77.

13. Tao, R. and A. Sugiura. 1987. Cultivar identification of Japanese persimmon by leaf isozymes. HortScience 22 : 932-935.

14. Yamaguchi, M., A. Yomoda and K. Hinata. 1990. Varietal differences in response to low temperature treatment for callus formation in anther culture of rice. Japan. J. Breed. 40:193-198.

培羡したカキのシュートからの発根能力の品種間差異

福井博一・西元和男 - 中村三夫

岐阜大学監学部 501-11 岐皁市柳戸 1-1

\begin{abstract}
摘 要
カキ95品種とマメガキ，アメリカガキ，リュウキュ $30 \%$ 以下の低い発根性を示した.また, 23 品種は $40 ６ 0 \%$ ウマメガキを用い, in vitroでの発根能力を調查した. の発根性を示し，16品種は70\%以上の高い発根能力が 供試したシュートは，茎頂培舊後窒素成分を $1 / 2$ に みられた，樹勢が強い品種は発根能力が高いものが多 した MS 培地に zeatin を $10^{-5} \mathrm{M}$ 添加した培地で 2 年間 かった，完全渋がキ（PCA）には発根能力の低いもの 継代培盖したもので, 発根処理として $\alpha$-naphthy] が多かった，発根数と根長との関係から供試品種を 3 acetamide 粉末 (0.4\%含有) を处理した。供試品種の 群に分類することができた。
\end{abstract}

